\title{
Comparative cytogenetic studies of Bufo ictericus, B. paracnemis (Amphibia, Anura) and an intermediate form in sympatry
}

\author{
MFC Azevedo ${ }^{1}$, F. Foresti ${ }^{2}$, PRR Ramos ${ }^{3}$ and $\mathrm{J} \mathrm{Jim}^{1}$ \\ ${ }^{1}$ Departamento de Zoologia, Instituto de Biociências, UNESP, Botucatu, SP, Brazil. \\ ${ }^{2}$ Departamento de Morfologia, Instituto de Biociências, UNESP, Botucatu, SP, Brazil. \\ ${ }^{3}$ Departamento de Física e Biofísica, Instituto de Biociências, UNESP, Botucatu, SP, Brazil.
}

\begin{abstract}
Specimens of Bufo ictericus, Bufo paracnemis and a third type, considered an intermediate subgroup between these species, were cytogenetically studied by conventional Giemsa staining, C-banding and staining of the nucleolus organizer region (NOR). The nuclear DNA content and seroproteins were also analyzed to characterize these species, and verify the possibility of hybridization between them. Karyotypes and cytogenetic markers were essentially equal on the basis of the methods used. The DNA nuclear content found was $6.25 \pm 0.30 \mathrm{pg} / \mathrm{DNA}$ in Bufo ictericus; $7.57 \pm 0.40 \mathrm{pg} / \mathrm{DNA}$ in Bufo paracnemis and $7.04 \pm 0.29 \mathrm{pg} / \mathrm{DNA}$ in the intermediate subgroup. Eletrophoresis of total blood serum in Bufo ictericus, Bufo paracnemis and the intermediate specimens revealed a remarkable difference in the patterns of the protein bands whose molecular weight corresponded to that of albumin. While the parental species presented two different bands, the intermediate form presented 4 . However, only three of these bands were seen in each specimen. The results obtained pointed to a high probability for natural hybridization between Bufo ictericus and Bufo paracnemis in the site and specimens studied.
\end{abstract}

Key words: Bufo, hybridization, cytogenetics, nuclear DNA, seroproteins.

Received: July 26, 2002; Accepted: March 10, 2003.

\section{Introduction}

Anura have usually been studied from the morphological and ecological point of view. The Bufo genus is of particular interest for studies regarding evolution and reproductive isolation mechanisms (Haddad et al., 1990), due to its cosmopolitan distribution and easy interbreeding in nature. Many authors have reported hybridization among the members of this genus in areas of sympatry (Blair, 1941; Thornton, 1955; Sullivan, 1986; Schlyter et al., 1991; Gergus et al., 1999 and Malmos et al., 2001). According to Wells (1977), the high frequency of hybridization can be explained by the reproductive mechanisms, such as external fertilization or the non-territoriality of observed in the group.

"Pre-zygotic" mechanisms of reproductive isolation prevent inter-species breeding while "post-zygotic" mechanisms do not always prevent the formation of descendents (Mayr, 1977). However, hybrids are not very successful due to sterility, or either partial or total lack of viability.

Send correspondence to Marisa Fagundes Carvalho de Azevedo. Departamento de Morfologia, Instituto de Biociências - UNESP, Campus de Botucatu, Distrito de Rubião Junior, C.P. 510, 18618-000 Botucatu, SP, Brazil. Phone/Fax: 0055-14-6802.6264. E-mail: marisafca@yahoo.com.
Blair (1955) believes that natural selection reinforces isolation mechanisms against hybridization in the form of a handicap against the hybrid in the competition with the parental types. Hybridization has attracted the interest of taxonomists and evolutionists because the study of this process in nature is of great value in obtaining answers to questions regarding the mechanisms involved in the process of evolution and species formation in the group. Even so, little effort has been made toward obtaining consistent data regarding hybridization success in nature. Therefore, the few isolated facts available in the literature are extremely useful in the evaluation of this part of the evolutionary process, according to Blair (1974).

Kloss (1972) reported the existence of inter-gradient forms between Bufo ictericus and B. paracnemis in transition zones between brush, prairies, forest, and clearings. Jim (1980) also refers to the "topo da cuesta", an area located in Botucatu, São Paulo, Brazil, as an intermediate area where these species occur, and reported the difficulties encountered in identifying the material collected in this region due to the morphological variations presented by the samples collected. More recently, Kasahara et al. (1998) have reported the occurrence of a Bufo specimen with an intermediate phenotype between $B$. paracnemis and $B$. 
ictericus. The occurrence of these intermediary types could have resulted from forest clearing and damming of water courses, which cause environmental alterations and affect the degree of isolation among the species (Blair, 1941). The increase in the degree of interaction among these species could be interfering in their reproductive strategies, affecting the hybridization frequency (Gergus et al., 1999).

Bufo ictericus and B. paracnemis are phylogenetically closely related (Blair, 1972; Frost, 1985), and the intermediate forms observed could be due to the anatomical similarities, or the possible occurrence of crossbreeding. The purpose of this study was to enable a better understanding of the relationships between Bufo species and taxonomic studies of the group by characterizing the $B$. ictericus and B. paracnemis samples found in the region of Botucatu, São Paulo, Brazil, and also to test the hypothesis of hybridization between these species by comparing the results obtained from samples considered as parentals and supposedly hybrids (anatomically intermediate).

\section{Material and Methods}

Seven of Bufo ictericus specimens, 4 of $B$. paracnemis, and 4 of an intermediate form (Figure 1), were collected in a man-made lake with shoreline vegetation at Estância Funari, Botucatu, São Paulo, Brazil (S. $22^{\circ} 53^{\prime} 12,9^{\prime \prime}$ and W. 48 $\left.29^{\prime} 46,6^{\prime \prime}\right)$. The collection site was selected because it was an altered environment.

All the specimens, after sacrifice, were fixed in $10 \%$ formaldehyde, preserved in $70 \%$ alcohol and kept in the collection of the Department of Zoology - UNESP, Botucatu, São Paulo, Brazil.

\section{Cytogenetic techniques}

Mitotic cells were obtained by the injection of a biological yeast solution, as described by Cole and Leavens (1971), followed by lymphocyte cellular culture as described by Fenocchio and Bertollo (1988). For staining, the slides were covered with Giemsa solution buffer. For the determination of the number and location of Nucleolus Organizer Regions (NORs) in the karyotypes, silver-ion $\left(\mathrm{AgNO}_{3}\right)$ impregnation was used according to a method originally described by Howell and Black (1980). C-banding pattern was obtained as proposed by Sumner (1972). The karyotypes of the species under study were not different from those of other populations previously studied. Therefore, the formats of distribution and chromosome
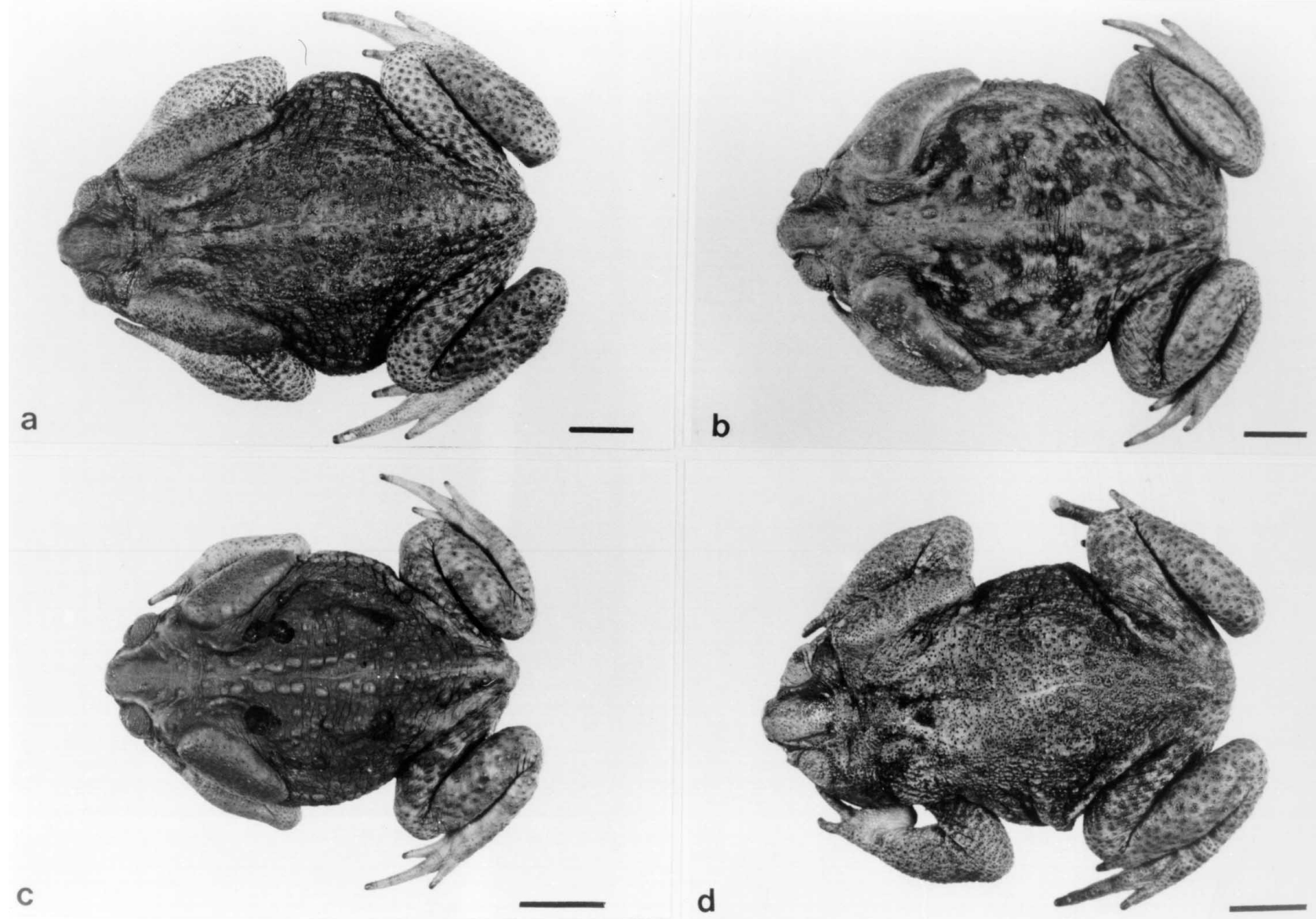

Figure 1 - Representative individuals of the species studied. (a) Bufo ictericus; (b) Bufo paracnemis; (c e d) Intermediate Type. Bar $=2 \mathrm{~cm}$. 
presentation were according to the system used by Blair (1972) and Kasahara et al. (1996), among others.

\section{Nuclear DNA quantification}

Blood cell smears from each specimen were prepared as described by Gold and Price (1985), with 10-minute hydrolysis. Quantitative analyses of the nuclei were performed with the software OPTIMAS, 4.1 version.

\section{Seroprotein electrophoresis}

Seroproteins were studied as described by Hames and Rickwood (1990). The method of alkaline electrophoresis $(\mathrm{pH}=9.0)$ was used, in polyacrylamide gel, in separate containers, at $10 \%$ concentration in the separation gel, and at $4 \%$ in the topping gel.

\section{Results}

The diploid number was $2 \mathrm{n}=22$ in Bufo ictericus, $B$. paracnemis and the individuals considered as intermediate forms. All of chromosomes were submetacentric and metacentric in all samples analyzed. The presence of secondary constrictions was observed on the short arm of pair 7, coinciding with the NORs (Figure 2). This description is the same as that decrypted by Blair (1972) and Kasahara et al. (1996).

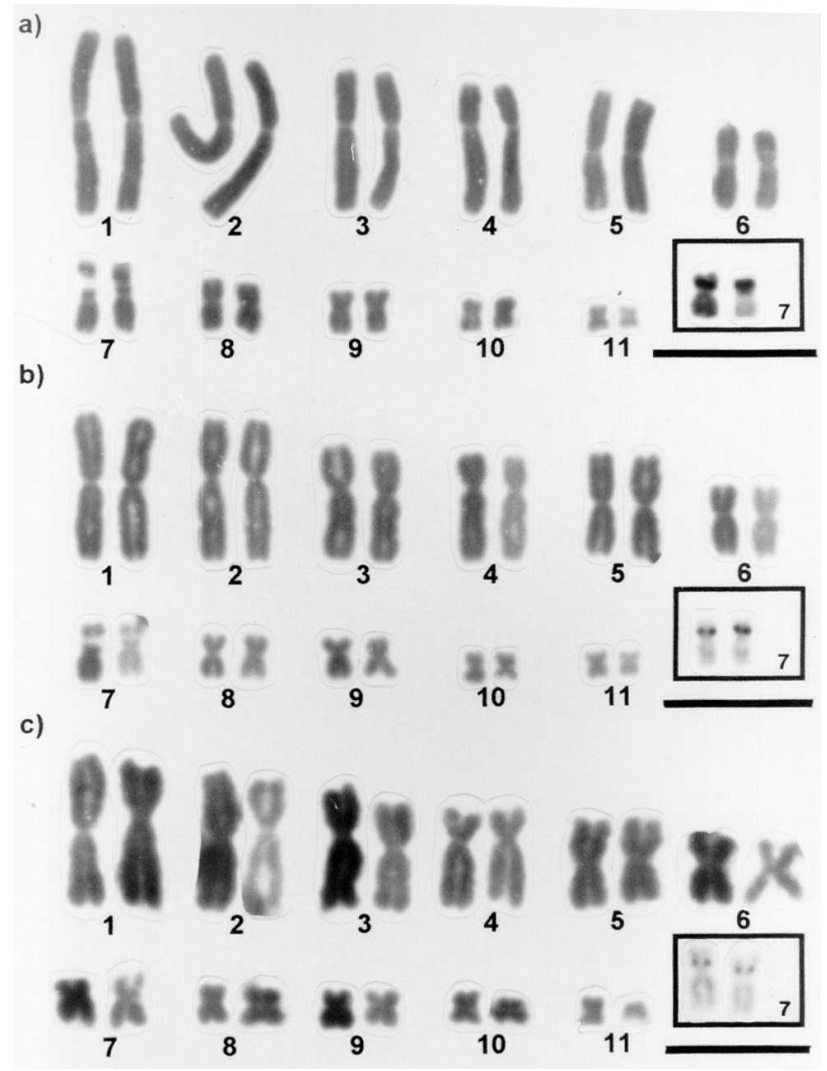

Figure 2 - Karyotypes with details of the NOR-bearing pair in the boxes. (a) Bufo ictericus; (b) Bufo paracnemis; (c) Intermediate Type. Bar $=10 \mu \mathrm{m}$.
The detection of constitutive heterochromatin by the C-banding technique revealed that all preparations of $B$. ictericus, B. paracnemis, and the intermediate form studied showed positive marks in the centromeric regions of all chromosomes, which were more evident in the larger pairs. In the majority of metaphases, pair 7 presented a heterochromatic interstitial block, coincident with the secondary constriction. Faint telomeric and interstitial marks could be observed in some chromosomes of some metaphases (Figure 3). In one individual of the B. paracnemis sample, 12 silver-stained metaphases were examined. Five of them presented centromeric marks in all chromosomes (Figure 4).

The average nuclear DNA content found in $B$. ictericus was $6.25 \pm 0.30 \mathrm{pg} \mathrm{DNA} /$ nucleus, in $B$. paracnemis, it was $7.57 \pm 0.40 \mathrm{pg}$ and the intermediate form presented an average of $7.04 \pm 0.29 \mathrm{pg}$ DNA/nucleus (Table 1).

Eletrophoresis of total blood serum in Bufo ictericus, Bufo paracnemis and the intermediate specimens revealed a remarkable difference in the patterns of the protein bands whose molecular weight corresponded to that of albumin (Figure 5). The analysis of these bands indicated that both species considered as parental presented at least one large band whereas the intermediate form presented at least three distinct bands.

\section{Discussion}

\section{Cytogenetics}

The karyotypes of B. ictericus, B. paracnemis and the form with intermediate characteristics between the first two, shared the same karyotype pattern observed in practically all the species of the genus, in line with the report by Bogart (1972). Henderson et al. (1972) and Hsu et al. (1975) have already observed that NORs are usually found in zones of secondary constriction, as seen in the present work. In general, these marks exhibited equivalent sizes in the same metaphase.

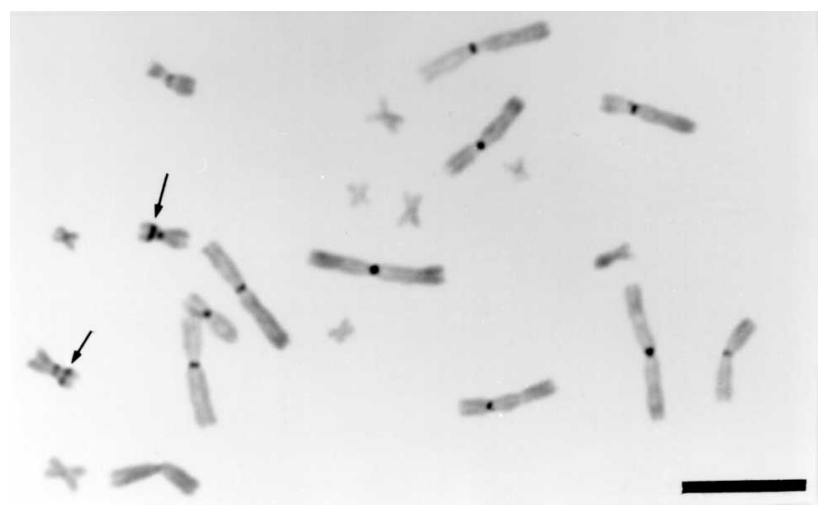

Figure 3 - Bufo paracnemis metaphase submitted to the silver staining technique presenting marks in the centromeric regions of the chromosomes. Arrows point to NORs on the chromosomes of pair 7. Bar $=10 \mu \mathrm{m}$. 
a)

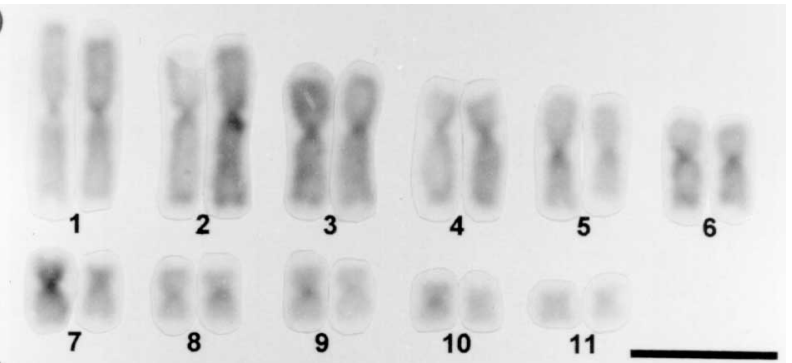

b)

c)
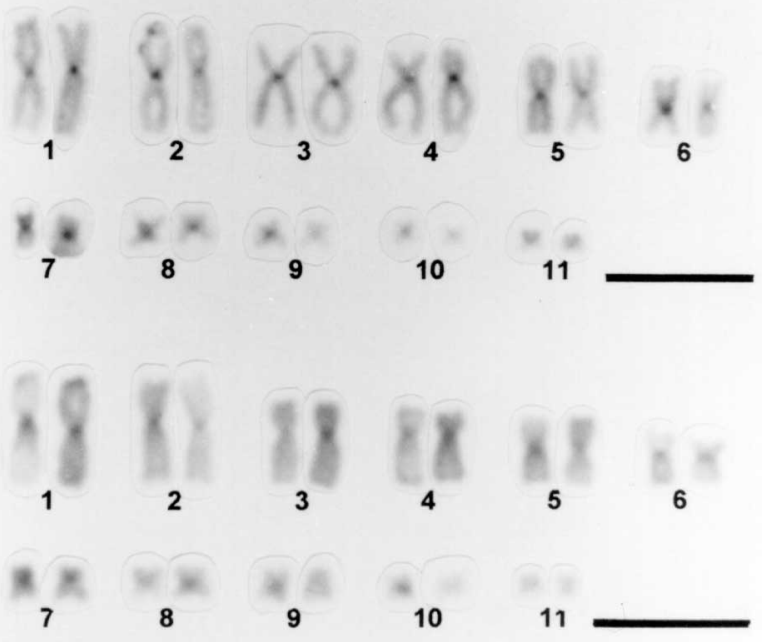

Figure 4 - Karyotypes stained according to the C-banding technique. (a) Bufo ictericus; (b) Bufo paracnemis; (c) Intermediate Type. Bar $=10 \mu \mathrm{m}$.

Table 1 - Diploid number and DNA content values, in picograms (pg), observed in the Bufo species and in the Intermediate form analyzed.

\begin{tabular}{lccc}
\hline & $\begin{array}{c}\text { Toads analyzed } \\
(\mathrm{M} / \mathrm{F})\end{array}$ & 2n & $\begin{array}{c}\text { Nuclear DNA } \\
\text { content }(\mathrm{pg})\end{array}$ \\
\hline Bufo ictericus & $5 / 2$ & 22 & $6.25+0.30$ \\
Bufo paracnemis & $3 / 1$ & 22 & $7.57+0.40$ \\
Intermediate form & $3 / 1$ & 22 & $7.04+0.29$ \\
\hline
\end{tabular}

M: Male; F: Female.

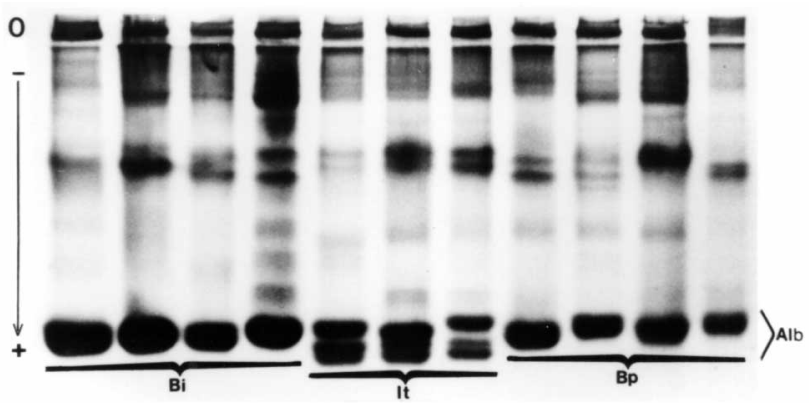

Figure 5 - Polyacrylamide gel electrophoresis showing the characteristic pattern of blood serum proteins of Bufo ictericus (Bi), Bufo paracnemis (Bp) and the Intermediate Type (It). O: Origin; Alb: Bands corresponding to albumin.
In amphibians, especially in Anura, NORs tend to be coincident with positive C-band regions, and may present large C-band positive blocks associated with them (King, 1988, 1990; King et al., 1990). With regard to constitutional heterochromatic detection, the species $B$. ictericus and $B$. paracnemis and the intermediate form studied in this research were $\mathrm{C}$-band positive in the centromeric region in all chromosomes. In the majority of the metaphases, pair 7 showed an interstitial C-band, coinciding with the region of secondary constriction and with NORs. This pattern did not differ from those found in the other species belonging to the marinus group (Schmid, 1978, 1980; Schmid and Almeida, 1988; Kasahara et al., 1996), based on which Kasahara et al. (1996) suggested that the pattern observed could characterize this morphological group.

In one B. paracnemis specimen studied herein, centromeric marks were observed in metaphases submitted to silver-staining. According to Sumner (1990 although of wide spread use, this method is not specific for NORs, since heterochromatin, kinetocore or other acid proteins may also occasionally be marked. However, these structures, when marked, are easily distinguished from NORs by clear differences in shape and color, as observed here.

The results obtained in the application of these cytogenetic techniques did not permit the differentiation of the species. However, the karyotypic stability described for these species was also identified in the samples from the Botucatu region, São Paulo, Brazil.

\section{Nuclear DNA content}

Quantification of nuclear DNA has been conducted in various frog species before and the data obtained have demonstrated that the quantity of nuclear DNA is constant for each species. Therefore, as a particular characteristic, it might be used to distinguish each given species (Herrero et al., 1993; Cavallo et al., 2002). Mean nuclear DNA content was $6.25 \pm 0.30 \mathrm{pg}$ DNA/nucleus in B. ictericus and $7.57 \pm$ $0.40 \mathrm{pg}$ in $B$. paracnemis, while in the intermediary form it was $7.04 \pm 0.29 \mathrm{pg}$ DNA/nucleus, characterizing the latter as an intermediate form between $B$. ictericus and $B$. paracnemis. Comparisons between parental and intermediary types showed significantly different values only in parental types (Table 1). Therefore, under the given conditions, the methodology utilized can be considered effective at the level of species, in systematic studies of the group. Furthermore, the DNA-nuclear content found in the intermediate forms showed an intermediary value between the means obtained in the other two species, suggesting the occurrence of a hybridization process between $B$. ictericus and $B$. paracnemis. The same analysis was done by Cavallo et al. (2002), in a study of diploid and tetraploid populations of Bufo viridis and they considered as hybrids the triploid individuals found in one population.

This approach was also used by Diaz (1986), who considered that the nuclear DNA content could be a useful 
parameter in the phylogenetic analysis of that group. This is based on the fact that many closely related species possess the same diploid number and very similar, or even identical, chromosomal morphology, exhibiting, nonetheless, considerable difference in nuclear DNA content (revised by King, 1990). Northland et al. (1990) also considered that comparative studies of nuclear DNA content were relevant, when comparisons were made among groups with relatively close phylogenic characteristics.

\section{Seroprotein electrophoresis}

With the results obtained with the electrophoresis technique for the protein bands whose mobility corresponded to that of albumin, it was possible to observe a clear and neat difference between the band patterns of the intermediate types and the species $B$. ictericus and $B$. paracnemis. The two latter species were identified by two distinct bands in the region corresponding to the albumin while four bands were observed in the intermediate forms, three in each animal.

This is probably not a populational polymorphism as described by Bertini and Cei (1960), because small populations possess reduced heterozygosity levels (Futuyma, 1992). The polymorphism found in B. ictericus and $B$. paracnemis differs widely in the patterns of albumin bands from that found in the intermediate forms. Furthermore, there is also the possibility of hybridization between one of the two parental species studied in this work and another species found in the study site, such as Bufo crucifer, for example. However, the species $B$. ictericus and $B$. paracnemis were selected for this study because they are morphologically more similar to the intermediate form.

According to Sage and Selander (1979), protein electrophoresis can reveal hybridization zones because they sometimes contain rare alleles not found in any of the parental semi-species. Such alleles may have resulted from a high mutation index in the hybrid genoma, or be formed by intra-genetic recombination between different alleles of the parental populations. The results, therefore, suggest that hybridization occurs between $B$. ictericus and $B$. paracnemis.

\section{Acknowledgments}

Our thanks to Shirlei M. Recco-Pimentel for the support in methodology and to Celio F. B. Haddad for suggestions and to Claudio Oliveira for critical reviewing of the manuscript. This work was supported by CAPES, CNPq, and FAPESP.

\section{References}

Bertini F and Cei JM (1960) Observaciones electroforeticas en seroproteinas de poblaciones argentinas de Bufo arenarum. Rev Soc Argent Biol 36(7-8):356-362.

Blair AP (1941) Variation, isolating mechanismis and hybridization in certain toads. Genetics 26:398-417.
Blair WF (1955) Mating call and stage of speciation in the Microhyla olivacea - M. carolinensis complex. Evolution 9:469-480.

Blair WF (1972) Evidence from hibridization. Evolution in the genus Bufo. Austin, University of Texas Press, Texas, pp 196-232.

Blair WF (1974) Character displacement in frogs. Amer Zool 14:1119-1125.

Bogart JP (1972) Karyotypes. In: Blair WF (ed) Evolution in the genus Bufo. Austin, University of Texas Press, Texas, pp 171-195.

Cavallo D, De Vita R, Eleuteri P, Borkin L, Emechenko V, Odierna G and Balletto E (2002) Karyological and flow cytometric evidence of triploid specimens in Bufo viridis (Amphibia Anura). Eur J Histochem 16(2):159-164.

Cole CJ and Leavens CR (1971) Chromosome preparations of amphibians and reptiles: improved technique. Herpetol Rev 3(6):102.

Díaz NF (1986) Biosistemática de los Leptodactylidae chilenos. An Mus Hist Nat Valparaíso 17:65-85.

Fenocchio AS and Bertollo LAC (1988) A simple method for fresh-water fish lymphocyte culture. Rev Brasil Genet 11(4):847-852.

Frost DR (1985) Amphibian Species of the World. Allen Press and the Association of Systematics Collections. Lawrence, Kansas. pp 723.

Futuyma, DJ (1992) Biologia Evolutiva. Sociedade Brasileira de Genética/CNPq. Ribeirão Preto, São Paulo. pp 631.

Gergus EWA, Malmos KB and Sullivan BK (1999) Natural hybridization among distantly related toads (Bufo alvaris, Bufo cognatus, Bufo woodhousii) in Central Arizona. Copeia 2:281-286.

Gold JR and Price HJ (1985) Genome size variation among north american minnows (Cyprinidae). I. Distribution of the variation in five species. Heredity 54:297-305.

Haddad CFB, Cardoso AJ and Castanho LM (1990) Hibridação natural entre Bufo ictericus e Bufo crucifer (Amphibia: Anura). Rev Brasil Biol 50(3):739-744.

Hames BD and Rickwood D (1990) Gel electrophoresis of proteins. Oxford University Press, New York, pp 383.

Henderson AS, Warburton D and Atwood KC (1972) Location of ribosomal DNA in the human chromosome complement. Proc Natl Sci 69:3394-3398.

Herrero P, Lopezjurado LF, Arano B and Garciaparis M (1993). Karyotype analyses and nuclear-DNA content of Bufobrongersmai hoogmoed. J Herpetol 27(4):463-465.

Howell WM and Black DA (1980) Controlled silver-staining of nucleolus organizer regions with a protective colloidal developer: a 1-step method. Experientia 36:1014-1015.

Hsu TC, Spirito SE and Pardue ML (1975) Distribution of 18+28S ribosomal genes in mammalian genomes. Chromosoma 53:25-36.

Jim J (1980) Aspectos Ecológicos dos Anfíbios Registrados na Região de Botucatu, Estado de São Paulo (Amphibia, Anura). Doctoral Thesis, Instituto de Biociências, Universidade de São Paulo, São Paulo, Brazil.

Kasahara S, Silva APZ and Haddad CFB (1996) Chromosome banding in three species of Brasilian toads (Amphibia Bufonidae). Rev Brasil Genet 19(2):237-242. 
Kasahara S, Silva APZ and Gruber SL (1998) Use of lymphocyte cultures for BrdU replication banding patterns in anuran species (Amphibia). Genet Mol Biol 21(4):471-476.

King M (1988) The interrelationship of G-banding, C-banding pattern and nucleolus organizer structure in anuran amphibians. In: Brandam PE (ed) Kew Chromosome Conference 111, pp 51-63.

King M (1990) Amphibia. In: John B (ed) Animal Cytogenetics. Gebrüder Borntraeger, Berlin. pp 2, 241.

King M, Contreras N and Honeucutt RL (1990) Variation within and between nucleolar regions in Australian hylid frogs (Anura) shown by $18 \mathrm{~S}$ and $28 \mathrm{~S}$ "in situ" hybridization. Genetica 80:17-29.

Kloss GR (1972) Os Rhabdias dos Bufo do grupo Marinus. Um estudo de espécies crípticas (Nematoda: Rhabditoidea). Doctoral Thesis, Universidade de São Paulo, São Paulo, Brazil.

Malmos KB, Sullivan BK and Lamb T (2001) Calling behavior and directional hybridization between two toads (Bufo microscaphus $\mathrm{x}$ B-woodhousii) in Arizona. Evolution 55(3):626-630.

Mayr E (1977) Populações, Espécies e Evolução. EdUSP, São Pulo, Brazil. pp 485.

Northland I, Capetillo J, Iturra P and Veloso A (1990) Nuclear DNA content and karyosystematic relationships of species grouped in primitive tribes of Leptodactylidae (Amphibia Anura). Rev Brasil Genet 13(2):247-254.
Sage RD and Selander RK (1979) Hybridization between species of the Rana pipiens complex in central Texas. Evolution 33:1069-1088.

Schlyter F, Hoglund J and Stromberg G (1991) Hybridization and low numbers in isolated populations of the Natterjack, Bufo calamita, and the green toad Bufo viridis, in Southern Sweden: possible conservation problems. Amphibia-Reptilia 12:267-281.

Schmid M (1978) Chromosome banding in Amphibia. I. Constitutive heterochromatin and nucleolus organizer regions in Bufo and Hyla. Chromosoma 66:361-388.

Schmid M (1980) Chromosome banding in Amphibia. IV. Differentiation of GC- and AT- rich chromosome regions in Anura. Chromosoma 77:83-103.

Schmid M and Almeida CG (1988) Chromosome banding in Amphibia. XII. Restriction endonucleases banding. Chromosoma 96:283-290.

Sullivan BK (1986) Hybridization between the toads Bufo microscaphus and Bufo woodhousei in Arizona: Morphological variation. Journal of Herpetology 20(1):11-21.

Sumner AT (1972) A simple technique for demonstrating centromeric heterochromatin. Exptl Cell Res 75:304-306.

Sumner AT (1990) Chromosome banding. Unwin Human, London. pp 433.

Thornton WA (1955) Interspecific hybridization in Bufo woodhousei and Bufo valliceps. Evolution 9:455-468.

Wells KD (1977) The social behavior of anuran amphibians. Anim Behav 25:666-693.

Editor: Yatiyo Yonenaga-Yassuda 